Jurnal Ilmu Dakwah Volume 39 No 2 (2019) 112-125

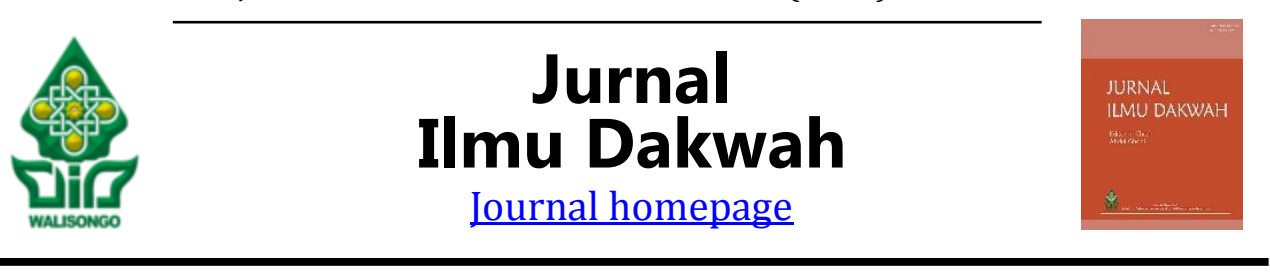

\title{
Reduksi Tingkat Stress pada Komunitas Purbalingga Street Art melalui Graffiti dan Mural
}

\author{
Eti Khusnul Khotimah'1, Alief Budiyono ${ }^{2}$ \\ ${ }^{1}$ Fakultas Dakwah, ${ }^{2}$ IAIN Purwokerto \\ Email: echiekh69@gmail.com; alief@iainpurwokerto.ac.id
}

\begin{abstract}
Many things can be done to reduce stress, one of them is through Graffiti and Mural. Both are recognized to reduce stress levels in a person. The purpose of this study is to find out how to reduce stress levels and differences in stress levels before and after treatment in the form of drawing graffiti and murals in the Purbalingga Street Art (PUSAR) community. This type of research is a quantitative quasi experiment. To measure stress levels, the instrument used is the Depression Anxiety Stress Scale (DASS). The stress difference was analyzed using the Wilcoxon signed rank test. The results of the study stated that graffiti and murals can cause a sense of fun and calm when the artist holds a pilox (spray paint) on the object of the wall. Then, there is a point in making graffiti that makes a graffiti artist feel satisfied to express and express emotions from within himself. So that what makes graffiti and murals can overcome problems and cause pleasure is when all emotions can be overflowed into his work. Furthermore, every member of the Purbalingga Street Art (PUSAR) community with different stress levels get different results. Statistical test results show a significant difference or decrease in stress levels in the study subjects with the results of $p$ value $=0.011$ ( $p$ value $<0.05$ ), so the hypothesis is accepted.
\end{abstract}

\section{Abstrak}

Banyak hal yang dapat dilakukan untuk mereduksi stress, salah satunya melalui Graffiti dan Mural. Keduanya diakui dapat mengurangi tingkat stress pada seseorang. Tujuan dari penelitian ini adalah mengetahui cara mereduksi tingkat stress dan perbedaan tingkat stress sebelum dan sesudah dilakukannya perlakuan berupa menggambar graffiti dan mural pada komunitas Purbalingga Street Art (PUSAR). Jenis penelitian ini adalah kuantitatif quasi eksperimen. Untuk mengukur tingkat stress, instrumen yang digunakan adalah skala Depression Anxiety Stress Scale (DASS). Perbedaan stress tersebut dianalisis menggunakan uji wilcoxon signed rank. Hasil penelitian menyatakan bahwa graffiti dan mural dapat menimbulkan rasa senang serta ketenangan ketika artist memegang pilox (cat semprot) pada obyek tembok. Kemudian, ada sebuah titik dalam pembuatan graffiti yang membuat seorang artist graffiti merasa puas untuk mengungkapkan dan mengekspresikan emosi dari dalam dirinya. Sehingga yang membuat graffiti dan mural dapat mengatasi masalah dan menimbulkan rasa senang adalah saat semua emosi dapat diluapkan ke karyanya. 
Selanjutnya, setiap anggota komunitas Purbalingga Street Art (PUSAR) dengan tingkat stress yang berbeda mendapatkan hasil yang berbeda pula. Hasil uji statistik menunjukan perbedaan atau penurunan tingkat stress yang signifikan pada subjek penelitian dengan hasil p value $=0,011$ ( $\mathrm{p}$ value $<0,05$ ), sehingga hipotesis diterima.

Kata kunci: Graffiti dan Mural, Reduksi Stress, Komunitas Purbalingga Street Art (PUSAR)

\section{Pendahuluan}

Manusia adalah makhluk sosial yang tidak bisa lepas dari gaya hidup hedonis. Hal tersebut dilatarbelakangi oleh kemajuan ilmu teknologi yang menyebabkan kebutuhan manusia semakin meningkat.Dan tentunya menuntut untuk mengikuti arus perkembangan zaman serta tuntutan sosial lainnya. Apabila hal tersebut tidak dapat terpenuhi maka, akan menimbulkan kecemasan yang kemudian berujung pada perasaan stress. Stress adalah hal yang wajar dialami oleh semua orang mulai dari anak-anak, remaja sampai usia dewasa atau lanjut. Menurut Yosep, Stress merupakan sebuah reaksi fisik, mental, dan kimiawi dari dalam diri individu (Setiana\&Wiyani, 2017: 2). Stress adalah suatu kondisi yang menekan jiwa (batin) dan menimbulkan ketegangan syaraf yang berdampak pada jiwa. (Abidin, 2009:13-29).

Stress terjadi pada manusia dalam berbagai tingkatan. Stress juga menimpa pada remaja. Salah satu faktor yang menyebabkan stress atau depresi pada usia remaja pada usia remaja salah satunya adalah putus cinta. Pelampiasan stress pada anak usia remaja adalah dengan hal menyimpang seperti minum-minuman beralkohol serta mengkonsumsi obat-obatan terlarang seperti narkoba. Hal di atas sesuai dengan pendapat menurut Lensa Indonesia, Kepala Komisi Nasional Perlindungan Anak (Komnas Anak) merilis ada 7.526 anak usia remaja yang ditahan dalam penjara akibat kenakalannya mulai dari narkoba, pencurian, perkosaan dan lain-lain ( \&Arneliwati, 2015: 2 ).

Pada umumnya seseorang mengurangi stress dengan melakukan kegiatan seperti jalan-jalan, bermain game, shopping, olahraga, mendengarkan musik, dll. Berbeda dengan komunitas Purbalingga Street Art (PUSAR) yang mengurangi tingkat stress menggunakan art therapy. Art therapy adalah sebuah proses kreatif seperti menyanyi, bermain drama, menggambar, menari, dan membuat puisi (Sholihah, 2017: 8). Art therapy merupakan suatu proses kreatif dan bersifat ekspresif untuk mengelola stress dan melatih individu untuk melakukan coping stress, serta memperkuat rasa percaya diri (Permatasari, Marat, \& Suparman, 2017: 116-126). Yang dilakukan oleh komunitas Purbalingga Street Art (PUSAR) salah satunya yaitu art therapy dengan cara menggambar berupa graffiti dan mural untuk meluapkan segala emosinya.

Seni jalanan dalam komunitas ini disebut dengan writer atau artistserta mengekspresikan perasaannya melalui graffiti berbentuk huruf atau bahkan karakter untuk mencurahkan apa yang ada dihatinya dalam bentuk gambar menggunakan cat tembok dan pilox (Diets, 2018). Berdasarkan wawancara dengan anggota Komunitas Purbalingga Street Art (PUSAR), mereka seringkali mengalami problem dalam hidupnya. Penyebab stress yang menimpa mereka bermacam-macam, antara lain persoalan finansial, ketakutan dan rasa khawatir terhadap cita-cita atau masa depan, percintaan, keluarga, pertemanan dan sebagainya.

Penelitian sebelumnya, American Psychology Assosiation (APA) yang membahas mengenai dampak dan gejala akibat stress. Menurut Petrie, Booth dan Pennebaker bahwa gejala stress diantaranya sering marah, menunjukan ekspresi khawatir serta ketakutan, mengeluh, suka menangis dan terlalu banyak tidur atau kurang tidur (Rahmawati, 2014: 276-293 ). Menurut Priest, stress menyebabkan reaksi-reaksi 
fisik seperti gangguan pada jantung, tangan gemetar, syaraf leher bagian belakang merasa tegang dan kaku, gelisah, sulit tidur dan gangguan organ fisik lainnya (Abidin, 2012: 13-29). Faktor utama terjadinya stress yaitu berasal dari keluarga, lingkungan, atau sosial lainnya. Hal ini berkolerasi dengan penelitian yang dilakukan oleh NIOSH (National Institute for Occupational Safety and Health). Menurut Muchtar, sebabsebab terjadinya stress, dipengaruhi oleh usia, kondisi fisik dan faktor kepribadian baik dari lingkungan keluarga, cita-cita dan harapan yang dimiliki setiap individu (Anggraeni \& Jannah, 2014: 1-5).

Gejala yang sering dialami remaja yang tertimpa depresi dan diantaranya yaitu: merasa lemas, bibir kering, kringat dingin, mengalami khawatir atau cemas berlebihan, takut, jantung berdebar dan ada pula yang sulit tidur bahkan tidak nafsu makan. Gejala stress di atas merupakan hal yang umumnya orang lain alami. Berdasarkan pada studi pendahuluan penulis anggota Komunitas Purbalingga Street Art (PUSAR) yang rata-rata anggotanya adalah anak remaja, diketahui bahwa melalui graffiti dan mural seseorang dapat mengkspresikan diri dengan meluapkan segala keresahan dan segala permasalahan yang sedang dialaminya. Kegiatan tersebut menurut penulis unik dan menarik. Sebab, seni jalanan selalu dianggap sebagai perusak fasilitas umum dengan aksi vandalisme yaitu dengan melakukan aksi coret-

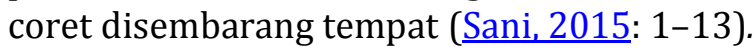

Dari hasil studi pendahuluan, sebagian remaja ini (PUSAR) menyatakan bahwa mereka mendapatkan kenyamanan setelah melakukan kegiatan corat coret ini. PUSAR memiliki prosedur saat menggambar di jalanan agar mereka dapat mengungkapkan kondisi yang dialami melalui ide kreatif dengan tenang. Kegiatan menggambar di jalanan menurutnya mampu memghilangkan depresi dan stress yang menimpanya. Mereka meluapkan kegelisahan melalui semprotan cat yang diberikan pada tembok. Berdasarkan kenyataan ini, sebetulnya penelitian ini dilakukan, dan jelas hal ini menguatkan hasil penelitian terdahulu, dengan perbedaan dalam obyek kajian dan fokus kajiannya.

\section{Metodologi}

Studi ini merupakan penelitian kuantitatif quasi eksperimen dengan menggunakan metode pre-test dan post-test yang beracuan pada skala DASS. Instrumen pertanyaan yang digunakan dengan menggunakan 42 butir pertanyaan. Instrumen DASS digunakan untuk mengukur tingkat stress pada komunitas Purbalingga Street Art (PUSAR) sebelum dan sesudah diberikan art therapy yaitu perlakuan berupa menggambar graffiti dan mural. Selanjutnya, Data kuantitatif dianalisis menggunakan uji wilcoxon signed rank.

Penelitian ini dilakukan pada komunitas Purbalingga Street Art (PUSAR). Karena jumlah anggota yang masih aktif menggambar graffiti dan mural pada komunitas Purbalingga Street Art (PUSAR) sekitar 10 orang. Jadi, populasi yang digunakan adalah artist atau writer pada komunitas Purbalingga Street Art (PUSAR) sebanyak 10 orang. Sementara itu, peneliti menggunakan teknik penarikan sampel purposive yaitu untuk menentukan kriteria khsusus terhadap sampel, khususnya pada orang-orang yang dianggap ahli (Priyono, 2008: 43).

a. Kriteria Inklusi

Penentuan kriteria sampel dalam penelitian ini mempunyai karakteristik atau dipilih dengan sebagai berikut:

a) Laki-laki usia 18-25 tahun

b) Memiliki stress ringan, sedang, berat dan sangat berat

c) Dapat menggambar graffiti atau mural

b. Kriteria Ekslusi 
Kriteria ekslusi adalah sampel yang tidak memenuhi kriteria inklusi dan sampel yang tidak bersedia dengan atau tanpa alasan tidak terlibat dalam penelitian.Di dalam penelitian ini ada sepuluh sampel penelitian yaitu Milk (19 tahun), Clantwo (23 tahun), Krd28 (20 tahun), Sph (18 tahun), Ruse (18 tahun), Diets (22 tahun), Gels (23 tahun), Alvian (18 tahun), Askom (19 tahun), Speteer (18 tahun).Angket dalam penelitian ini adalah pre-test dan post-test yang beracuan dengan skala Depretion Anxiety Stress Scale atau DASS. Depresi, ansietas dan stress dinilai dengan menggunakan kuesioner Depretion Anxiety Stress Scale atau DASS yang dikeluarkan oleh Psychology Foundation Australia (Masdar, dkk, 2016: 138-143). Menurut Akin dan Cetin, DASS atau Depretion Anxiety Stress Scale merupakan alat ukur yang efektif dan valid serta handal dalam menilai keadaan emosional untuk mengukur tingkat stress (Setiana \& Cristin, 2017: 2). DASS terdiri dari 3 skala yang dirancang untuk mengukur 3 jenis keadaan emosional, yaitu depresi, kecemasan, dan stres pada seseorang. Dan masing-masing skala terdiri dari 14 pertanyaan (Purwandari, 2016: 123).

Indikator bagi orang yang mengalami stress dapat diukur dan diketahui dengan menggunakan skala DASS tersebut. Berikut ini digambarkan tabel indikator yang digunakan.

Tabel 1

Indikator Kuesioner Depression Anxiety StressScale

\begin{tabular}{|c|c|c|}
\hline No. & Skala & Indikator Pertanyaan \\
\hline 1. & Depresi & $\begin{array}{ll}\text { - } & \text { Tidak ada perasaan positif } \\
\text { - } & \text { Tdak bisa melakukan sesuatu } \\
\text { - } & \text { Tidak ada harapan } \\
\text { - } & \text { Sedih dan tertekan } \\
\text { - } & \text { Kehilangan minat } \\
\text { - } & \text { Merasa tidak berharga } \\
\text { - } & \text { Merasa hidup tidak } \\
& \text { bermanfaat } \\
\text { - } & \text { Tidak mendapat kesenangan } \\
\text { - } & \text { Merasa putus asa } \\
\text { - } & \text { Tidak merasa antusias } \\
\text { - } & \text { Sulit berinisiatif }\end{array}$ \\
\hline 2. & Kecemasan & $\begin{array}{l}\text { - Mulut kering } \\
\text { - Sesak nafas } \\
\text { - Sering gemetar } \\
\text { - Berada di situasi cemas } \\
\text { - Pusing } \\
\text { - Berkeringat tanpa sebab } \\
\text { - Ketakutan } \\
\text { - Sulit menelan } \\
\text { - Sadar akan aksi gerak jantung } \\
\text { - Dekat dengan kepanikan } \\
\text { - Tidak berdaya }\end{array}$ \\
\hline 3. & Stress & $\begin{array}{l}\text { - Marah karena hal sepele } \\
\text { - Bereaksi berlebihan terhadap } \\
\text { situasi } \\
\text { - Sulit untuk beristirahat }\end{array}$ \\
\hline
\end{tabular}




\begin{tabular}{ll}
\hline No. $\quad$ Skala & \multicolumn{1}{c}{ Indikator Pertanyaan } \\
\hline & - Mudah merasa kesal \\
& - Menghabiskan banyak energi \\
& karena cemas \\
& - Tidak sabaran \\
& - Mudah tersinggung \\
& - Mudah marah \\
& - Sulit tenang saat merasa kesal \\
& - Sulit untuk sabar \\
& - Merasa gelisah \\
& - Sulit mentolerir gangguan \\
& - Mudah gelisah \\
\hline
\end{tabular}

Dari Tabel 1 dapat dihitung dengan menjumlahkan skor yang relevan dengan pilihan jawaban 0 -3. Nilai 0 tidak pernah sama sekali, 1 kadang-kadang, 2 sering, dan 3 sering sekali. Dengan demikian, skor stress diklasifikasikan menjadi 5 yaitu, normal dengan skala interval (0-14), stres ringan (15-18), stres sedang (19-25), stres berat (26-33), stres sangat berat ( $\geq 34$ ). Oleh karena itu, Kuisioner DASS 42 yang digunakan peneliti merupakan skala yang sudah tervaliditasi, sehingga tidak perlu dilakukan uji validitas dan reabilitas. Hal itu disebabkan karena nilai validitas dan reabilitas 0,91 yang diolah berdasarkan penilaian Cronbach's Alpha sudah sangat tinggi (Khofifah, 2015: 125-130). Penelitian ini bertujuan untuk mengetahui apakah graffiti dan mural dapat digunakan untuk mereduksi tingkat stress. Uji pre-test dilakukan kepada anggota komunitas Purbalingga Street Art (PUSAR) yang dapat menggambar graffiti dan mural dengan jumlah sampel 8 orang.

\section{Pembahasan}

\section{a. Lingkup Kajian Graffiti dan Mural}

Graffiti berasal dari kata Italia "grafitto" yang berarti guratan atau goresan, yang memiliki atau memberikan fungsi pada pemanfaatan aksi corat-coret (Sani, 2015: 2). Graffiti adalah seni rupa yang dibuat di atas dinding untukmenuliskan kalimat tertentu dengan menggunakan komposisi warna, garis, bentuk dan volume (Yuniar, 2017: 3). Graffiti merupakan sebuah symbol berupa nama atau identitas dari artist/writer tersebut.

Kata graffiti berasal dari bahasa latin yaitu graphium yang artinya tulisan (Budyastomo, 2018: 146-156). Menurut Kenneth Burke memandang dari teori Dramatisme, komunikasi merupakan cara berproses untuk menuangkan gagasan serta pengalaman(Widagdo, 2016: 24-34). Komunikasi dalam sebuah karya seni berupa penanda nama kota atau gang tertentu sebagai ciri khas dari kota itu sendiri. Hal ini sesuai dengan apa yang dilakukan oleh komunitas Purbalingga Street Art (PUSAR) yang menggambar graffiti disepanjang gang atau kota tertentu sebagai tanda daerah tersebut.

Mural berasal dari bahasa Latin yaitu murus yang artinya dinding (Asharhani, 2012: 56). Mural adalah gambar dengan ukuran besar yang dilukis pada dinding, langit-langit ruang, atau tempat permanen(Fachmi Ramadani, Hairunnisa, 2018). Menurut Susanto, Mural didenifisikan sebagai lukisan besar yang dibuat untuk mendukung ruang arsitektur (Susanto, 2002: 23).

Mural merupakan seni yang diekspresikan pada dinding yang bertujuan untuk mengaktualisasikan antara perilaku dan lingkungan sekitar (Candra, 2013: 234). Dengan demikian, yang dimaksud dengan graffiti dan mural dilihat dari perbedaannya adalah dari teknik penggarapannya. Sebab, ada sebuah titik dalam 
pembuatan graffiti yang membuat seorang artist graffiti merasa puas untuk mengungkapkan dan mengekspresikan emosi dari dalam dirinya.

\section{b. Graffiti dan Mural pada Komunitas Purbalingga Street Art (PUSAR)}

Komunitas Purbalingga Street Art (PUSAR) adalah komunitas yang berada di bawah naungan komunitas Urban Street Culture (USC) Purbalingga. Komunitas Purbalingga Street Art (PUSAR) adalah sebuah komunitas yang mewadahi seniman jalanan dalam mengekspresikan dirinya menjadi karya seni. Diantaranya yaitu seni graffiti dan mural yang biasanya dituangkan menjadi sebuah gambar di tembok atau dinding kayu. Komunitas Purbalingga Street Art (PUSAR) merupakan komunitas yang berisi anak remaja yang hobi menggambar dan sangat menyukai seni graffiti dan mural. Dengan demikian, graffiti dan mural yang dihasilkan oleh komunitas ini memberikan nuansa penuh warna yang menyampaikan pesan-pesan moral dibeberapa jalan kota Purbalingga. Jadi, yang dimaksud komunitas Purbalingga Street Art (PUSAR) oleh peneliti adalah komunitas di Purbalingga yang berisi seniman atau writer graffiti dan mural yang menyalurkan karyannya melalui hobi.

Kegiatan yang dilakukan oleh PUSAR bertujuan untuk mereduksi tingkat stress yang dialaminya. Reduksi diartikan pemotongan atau pengurangan, $(\underline{K B B I, 2018}$ : 167). Reduksi stress yang dimaksud penulis dalam penelitian ini adalah suatu proses yang diterapkan untuk menghilangkan atau mengurangi stress pada seseorang, seperti halnya yang dilakukan oleh komunitas Purbalingga Street Art (PUSAR) yang akan diteliti ini menggunakan graffiti dan mural untuk mereduksi tingkat stress.

\section{Hasil}

Studi ini berusaha untuk mengungkap kegiatan graffiti dan mural yang mampu mereduksi tingkat stress pada pelakunya, dalam hal ini adalah PUSAR. Berdasarkan skala DASS skor stress yang diambil dapat diklasifikasikan menjadi dua yang tergambar dalam tabel sebagai berikut;

Tabel 2

Skor Pre-test terhadap Populasi dan Sampel

\begin{tabular}{rrc}
\hline No. & Skor & Frekuensi \\
\hline 1. & $0-14$ & 2 \\
\hline 2. & $15-(\geq 34)$ & 8 \\
\hline \multicolumn{2}{c}{ Total } & 10 \\
\hline
\end{tabular}

Dari 10 artist graffiti dan mural yang diberikan pre-test dan post-test diperoleh hasil yaitu 2 artist mendapatkan skor dengan kategori normal dan 8 artist mendapatkan skor dalam kategori stess. Berdasarkan uji pre-test, maka ada 8 artist yang menjadi subjek penelitian. Penelitian dilakukan dengan waktu yang berbeda antara subjek yang satu dan yang lainya. Akan tetapi, ada pula subyek yang diteliti diwaktu bersamaan. Semua itu dilakukan sesuai kondisi dan keadaan dari artist graffiti dan mural. Oleh karena itu, peneliti menyesuaikan waktu dan tempat untuk memberikan pre-test dan post-test. Di bawah ini merupakan perolehan skor sebelum dan sesudah dilakukan perlakuan graffiti dan mural pada komunitas Purbalingga Street Art (PUSAR). Sehingga, terdapat perbedaan antara skor pre-test dan post-test. Berikut disajikan ke dalam tabel 3: 
Tabel 3

Perbedaan Skor Pre-test dan Post-test

\begin{tabular}{|c|c|c|c|c|c|c|c|}
\hline No & Nama & Pre & $\begin{array}{c}\text { Kategori } \\
\text { Pre-test }\end{array}$ & Post & $\begin{array}{l}\text { Kategori } \\
\text { Post-test }\end{array}$ & $\begin{array}{l}\text { Penurunan } \\
\text { skor }\end{array}$ & Ket. \\
\hline 1. & Clantwo & 36 & SSB & 24 & SS & 12 & $\mathrm{~T}$ \\
\hline 2. & Milk & 18 & SR & 2 & $\mathrm{~N}$ & 16 & $\mathrm{~T}$ \\
\hline 3. & Sph & 19 & SS & 14 & $\mathrm{~N}$ & 5 & $\mathrm{~T}$ \\
\hline 4. & Diets & 19 & SS & 7 & $\mathrm{~N}$ & 12 & $\mathrm{~T}$ \\
\hline 5. & Ruse & 22 & SS & 15 & SR & 7 & $\mathrm{~T}$ \\
\hline 6. & Alvian & 45 & SSB & 11 & $\mathrm{~N}$ & 34 & $\mathrm{~T}$ \\
\hline 7. & Krd28 & 34 & SB & 22 & SS & 12 & $\mathrm{~T}$ \\
\hline 8. & Giels & 23 & SS & 11 & $\mathrm{~N}$ & 12 & $\mathrm{~T}$ \\
\hline & $\begin{array}{l}\text { Keterangan } \\
\text { SR: Stress } \\
\text { SS: Stress }\end{array}$ & $\begin{array}{l}\text { ingan } \\
\text { edang }\end{array}$ & $\begin{array}{l}\text {-SB: Str } \\
\text {-SSB: St }\end{array}$ & $\begin{array}{l}\text { ss Ber } \\
\text { es san }\end{array}$ & at berat & $\begin{array}{l}-\mathrm{N} \text { : Normal } \\
-\mathrm{T} \text { : Turun }\end{array}$ & \\
\hline
\end{tabular}

Tabel di atas menunjukan perbedaan skor pre-test dan post-test pada artist graffiti dan mural. Hasil skor pre-test skala DASS 42 terhadap komunitas Purbalingga Street Art (PUSAR) terdapat penurunan. Diantaranya yaitu subjek Clantwo mendapat jumlah skor pre-test 36 (kategori stress sangat berat) dan jumlah post-test 24 (kategori stress sedang). Dengan demikian, ia mengalami penurunan 12 skor. Kemudian, Milk mendapat skor pre-test 18 (kategori stress ringan) dan posttestberjumlah 2 skor (kategori normal),ia mengalami penurunan 16 skor. Senada dengan Milk, Sph mendapat skor pre-test sejumlah 19 (kategori stress sedang) dan post-test 14 (kategori normal) ia mengalami penurunan 5 skor.

Diets mendapatkan skor pre-test 19 (kategori stress sedang) dan post-test sebanyak 7 skor (kategori normal). Dengan begitu, ia mengalami penurunan 12 skor. Selanjutnya, Ruse mendapatkan skor pre-test 22 (kategori stress sedang) dan posttest 15 (kategori stress ringan), sehingga ia turun 5 skor. Sementara itu, Alvian mendapatkan skor pre-test 45 (kategori stress sangat berat) dan post-test 11 (kategori normal) serta mengalami penurunan sebanyak 34 skor. Berbeda dengan Krd28 mendapatkan skor pre-test 34 (kategori stress berat) serta post-test 22 (kategori stress sedang) dan mengalami penurunan 12 skor Dan yang terakhir yaitu Giels mendapatkan skor pre-test 23 (kategori stress sedang) sertapost-test 11 (kategori normal) dan mengalami penurunan 12 skor. 
Awalnya peneliti ingin menggunkan statistik parametrik dengan uji paired test untuk hipotesis di atas, namun karena data penelitian tersebut tidak berdistribusi normal maka peneliti menggunakan alternatif lain yakni menggunakan uji wilcoxon signed ranks. Dari data tersebut kemudian diolah menggunakan uji wilcoxon signed ranks.

Tabel 4

Hasil Analisis Uji Wilcoxon Signed Rank

\begin{tabular}{lllcc}
\hline & & $\mathrm{N}$ & Mean Rank & Sum of Ranks \\
\hline Post Test $\begin{array}{c}- \\
\text { PreTest }\end{array}$ & NegativeRanks & $8^{\mathrm{a}}$ & 4.50 & 36.00 \\
\cline { 2 - 5 } & Positive Ranks & $0^{\mathrm{b}}$ & .00 & .00 \\
\cline { 2 - 5 } & Ties & $0^{\mathrm{c}}$ & & \\
\cline { 2 - 5 } & Total & 8 & & \\
\hline
\end{tabular}
a. Post Test $<$ Pre Test
b. Post Test $>$ Pre Test
c. Post Test $=$ Pre Test

\begin{tabular}{lr}
\hline & \multicolumn{2}{c}{ Post Test - Pre Test } \\
\hline$Z$ & $-2.552^{\mathrm{b}}$ \\
\cline { 2 - 2 } Aymp. Sig. (2-tailed) & .011
\end{tabular}

a. Wilcoxon Signed Ranks Test

b. Based on positive ranks.

Berdasarkan metode perhitungan yang dilakukan di dalam rumus Wilcoxon signed rank test, nilai-nilai yang di dapat adalah: nilai mean rank dan sum of ranks dari kelompok negatif ranks, positive ranks dan ties.Negativeranks artinya sampel dengan nilai kedua (post-test) lebih rendah dari nilai pertama (pre-test). Sehingga negative ranks atau selisih (negatif) adalah hasil antara sebelum dan sesudah dilakukan perlakuan berupa menggambar graffiti dan mural. Disini terdapat 8 data negatif $(\mathrm{N})$ yang artinya ke 8 artist graffiti dan mural mengalami penurunan ketika menggambar graffiti dan mural dari nilai pre-test ke nilai post-test. Mean rank atau rata-rata penurunan tersebut adalah sebesar 4.50 , sedangkan jumlah rangking negatif atau sum of ranks adalah sebesar 36.00 .

Positive ranks adalah sampel dengan nilai kedua (post-test) lebih tinggi dari nilai pertama (pre-test). Positive ranks atau selisih (positif) yaitu hasil antara sebelum dan sesudah dilakukan perlakuan berupa menggambar graffiti dan mural untuk pre-test dan post-test adalah 0 , baik itu pada nilai $\mathrm{N}$, mean rank maupun sum rank. Nilai 0 ini 
menunjukan tidak adanya peningkatan (penambahan) dari nilai pre-test ke nilai posttest.

Sementara itu, ties adalah nilai kedua (post-test)sama besarnya dengan nilai pertama (pre-test). Simbol N menunjukkan jumlahnya, Mean rank adalah peringkat rata-ratanya dan sum of ranks adalah jumlah dari peringkatnya. Ties merupakan kesamaan nilai pre-test dan post-test, dari data di atas nilai ties adalah 0 , sehingga dapat dikatakan bahwa tidak ada nilai yang sama antara pre-test dan post-test. Kemudian, untuk dasar pengambilan keputusan uji wilcoxon adalah: 1. Jika nilai Asymp.Sig < 0.05 maka hipotesis diterima, 2. Jika nilai Asymp.Sig > 0.05 maka hipotesis ditolak

Berdasarkan hasil output "Test Statistics", diketahui Asymp.Sig (2-tailed) bernilai 0.011. Karena 0.011 lebih kecil dari $<0.05$, maka dapat disimpulkan bahwa hipotesis diterima. Artinya ada perbedaan antara hasil sebelum dan sesudah dilakukan perlakuan berupa menggambar graffiti dan mural. Sehingga, dapat disimpulkan pula bahwa ada perbedaan kondisi stress sebelum dan sesudah pembuatan graffiti dan mural pada komunitas Purbalingga Street Art (PUSAR). Data di atas juga di dukung oleh pendapat dari subyek Milk yang mengatakan bahwa menggambar graffiti dan mural mampu mengurangi stress yang sedang dirasakan (Milk, 2018).

Berdasarkan penghitungan yang dilaksanakan tergambar data sangat jelas bahwa menggambar graffiti dan mural dapat menimbulkan rasa senang oleh pelakunya, yaitu anggota PUSAR. Menurut sebagian anggota PUSAR, ada sebuah titik dalam pembuatan graffiti yang membuat seorang artist graffiti merasa puas untuk mengungkapkan dan mengekspresikan emosi dari dalam dirinya. Dengan demikian, graffiti dan mural dapat menghasilkan ketenangan. Berbeda dengan cat, jadi yang dibahas bukan gambarnya tetapi proses menyemprotkannya juga mempengaruhi.

Dengan kata lain, yang membuat graffiti dan mural dapat mengatasi masalah dan menimbulkan rasa senang karena segala emosi dapat diluapkan semua ke karyanya. Oleh sebab itu, graffiti dan mural digunakan untuk mengurangi tekanan-tekanan yang berat. Hal tersebut dialami dan dilakukan oleh komunitas Purbalingga Street Art (PUSAR) dengan tujuan untuk mengekspresikan segala emosi serta mengaktualisasikan diri untuk mereduksi tekanan yang ada pada dirinya.

Lebih lanjut, Graffiti adalah coretan di dinding yang bernafaskan komposisi warna, titik, garis, volume, bentuk yang digunakan sebagai sarana komunikasi. (Clantwo, 2019). Pendapat tersebut juga sejalan dengan pendapat Malchiodi yaitu Expression through art, music, movement, or play can be ways to convey oneself without wordsand may be the primary form of communication in therapy (Malchiodi, 2006). Oleh karena itu menggambar merupakan sebagai sarana komunikasi atau mengungkapkan ekspresi segala emosi yang dirasakan oleh writer. Berikut ini merupakan hasil karya dari artist graffiti dan mural pada komunitas Purbalingga Street Art (PUSAR);

Tabel 5

Hasil karya Graffiti dan Mural PUSAR 


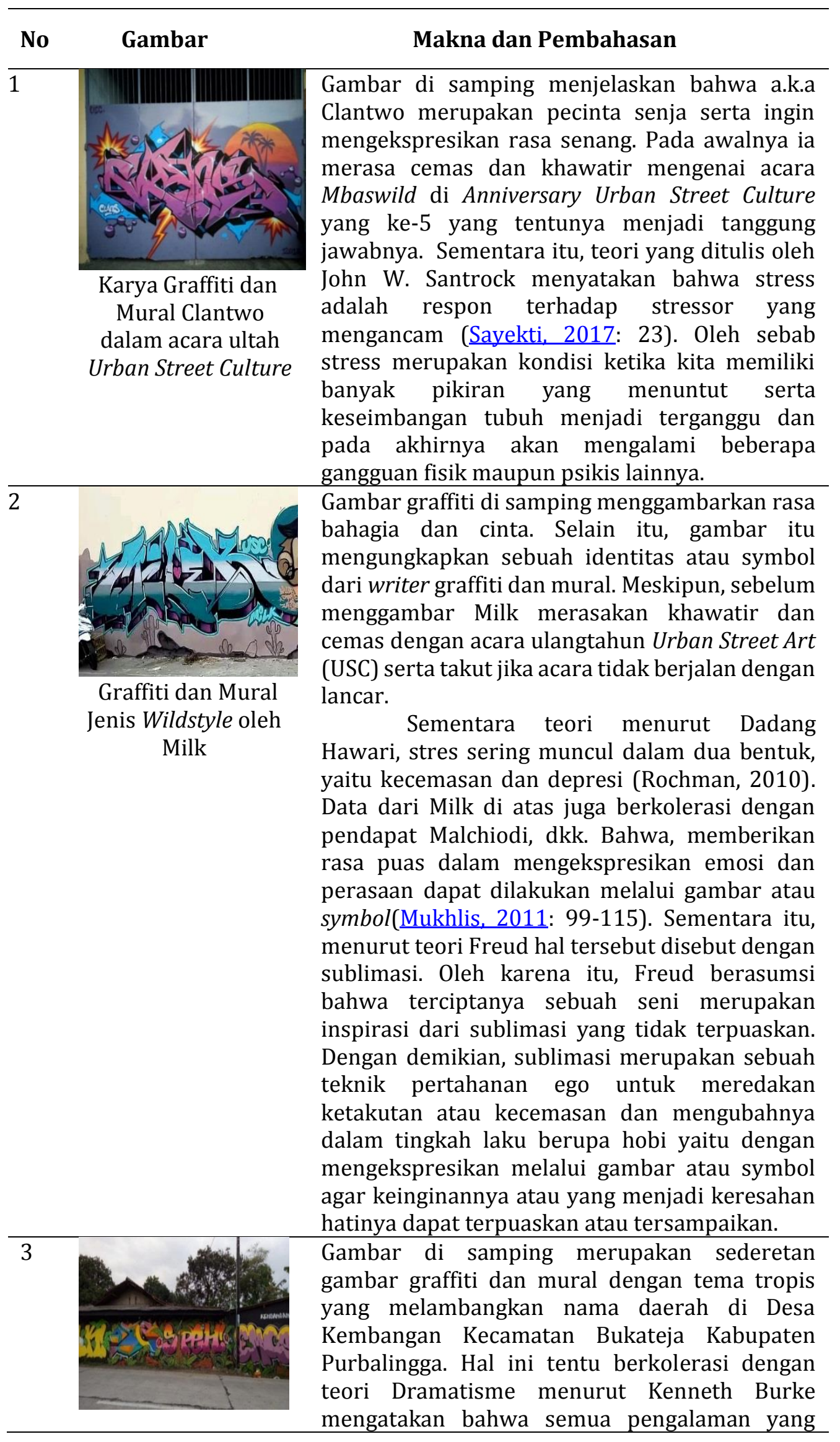




\begin{tabular}{|c|c|c|}
\hline No & Gambar & Makna dan Pembahasan \\
\hline & $\begin{array}{l}\text { Kolaborasi Graffiti } \\
\text { dan Mural di } \\
\text { desaKembangan }\end{array}$ & $\begin{array}{l}\text { mendasari mereka menuangkan gagasan yaitu } \\
\text { dengan cara berproses untuk aktifitas } \\
\text { komunikasi (Widagdo, 2016:24). } \\
\text { Sehingga, komunikasi dalam sebuah karya seni } \\
\text { bisa berupa penanda nama kota atau gang } \\
\text { tertentu sebagai ciri khas dari kota itu sendiri.Di } \\
\text { daerah tropis tentu banyak sekali tanaman dan } \\
\text { bunga-bunga. Gambar bunga tersebut bisa } \\
\text { diartikan Kembangan yang tak lain adalah nama } \\
\text { desa tersebut. Sebuah tempat para writer atau } \\
\text { artist mural seperti Milk, Sph, Alvian, dan Speteer } \\
\text { berkolaborasi dalam satu tembok di Jalan Raya } \\
\text { Kembangan Bukateja. }\end{array}$ \\
\hline 4 & $\begin{array}{l}\text { Graffit } \\
\text { Jenis } И\end{array}$ & $\begin{array}{l}\text { Gambar ini merupakan sebuah symbol. Menurut } \\
\text { teori Dramantisme oleh Kenneth Burke manusia } \\
\text { merupakan makhluk yang menggunakan symbol. } \\
\text { Penggunaan symbol dalam teori Dramantisme } \\
\text { menurut Suparno (2011)mencakup membuat, } \\
\text { menggunakan, bahkan menyalahgunakan symbol } \\
\text { (Widagdo, 2016: } 23) \text {. } \\
\text { Oleh sebab itu, seorang artist graffiti } \\
\text { memiliki kepuasan tersendiri dalam proses } \\
\text { pembuatan graffiti dititik tertentu. Dan gambar } \\
\text { yang dituangkan di dalam tembok merupakan } \\
\text { sebuah kreativitas yang berupa symbol dan } \\
\text { tentunya memiliki makna tersendiri bagi artist } \\
\text { graffiti itu sendiri. }\end{array}$ \\
\hline 5 & $\begin{array}{r}\text { Graffiti dan } \\
\text { Jenis Wildstyl } \\
\text { Ruse }\end{array}$ & $\begin{array}{l}\text { Gambar di samping menggambarkan kondisi } \\
\text { yang dirasakan Ruse saat itu adalah perasaan } \\
\text { khawatir dan ia juga dituntut harus bisa } \\
\text { menggambar dengan biaya yang seadanya. } \\
\text { Adapun stress menurut teori Lazarus dan } \\
\text { Launier adalah ketegangan fisik dan mental atau } \\
\text { emosional yang disebabkan oleh tekanan dan } \\
\text { tuntutan disekeliling manusia (Rochman, 2010: } \\
\text { 23). Sehingga, stressor adalah suatu yang } \\
\text { mengancam secara fisik maupun psikologis dan } \\
\text { menyebabkan kesedihan, kekecewaan serta } \\
\text { menimbulkankecemasan, kekhawatiran yang } \\
\text { berlebihan. }\end{array}$ \\
\hline 6 & $\begin{array}{l}\text { Graffiti dan Mural } \\
\text { oleh Alvian di }\end{array}$ & $\begin{array}{l}\text { Gambar tersebut memberikan pesan rasa rindu } \\
\text { yang mendalam kepada seorang wanita yang } \\
\text { dicintainya dengan inisial CHZ yang sangat cuek. } \\
\text { Alvian selalu resah dan cemas menunggu kabar } \\
\text { darinya tapi Alvian tetap menyukainya. Teori } \\
\text { hirarki kebutuhan menurut Maslow yang } \\
\text { membahas tentang penyebab stress salah } \\
\text { satunya yaitu kebutuhan akan rasa kasih sayang } \\
\text { dan kebutuhan akan harga diri atau self ekstem. }\end{array}$ \\
\hline
\end{tabular}




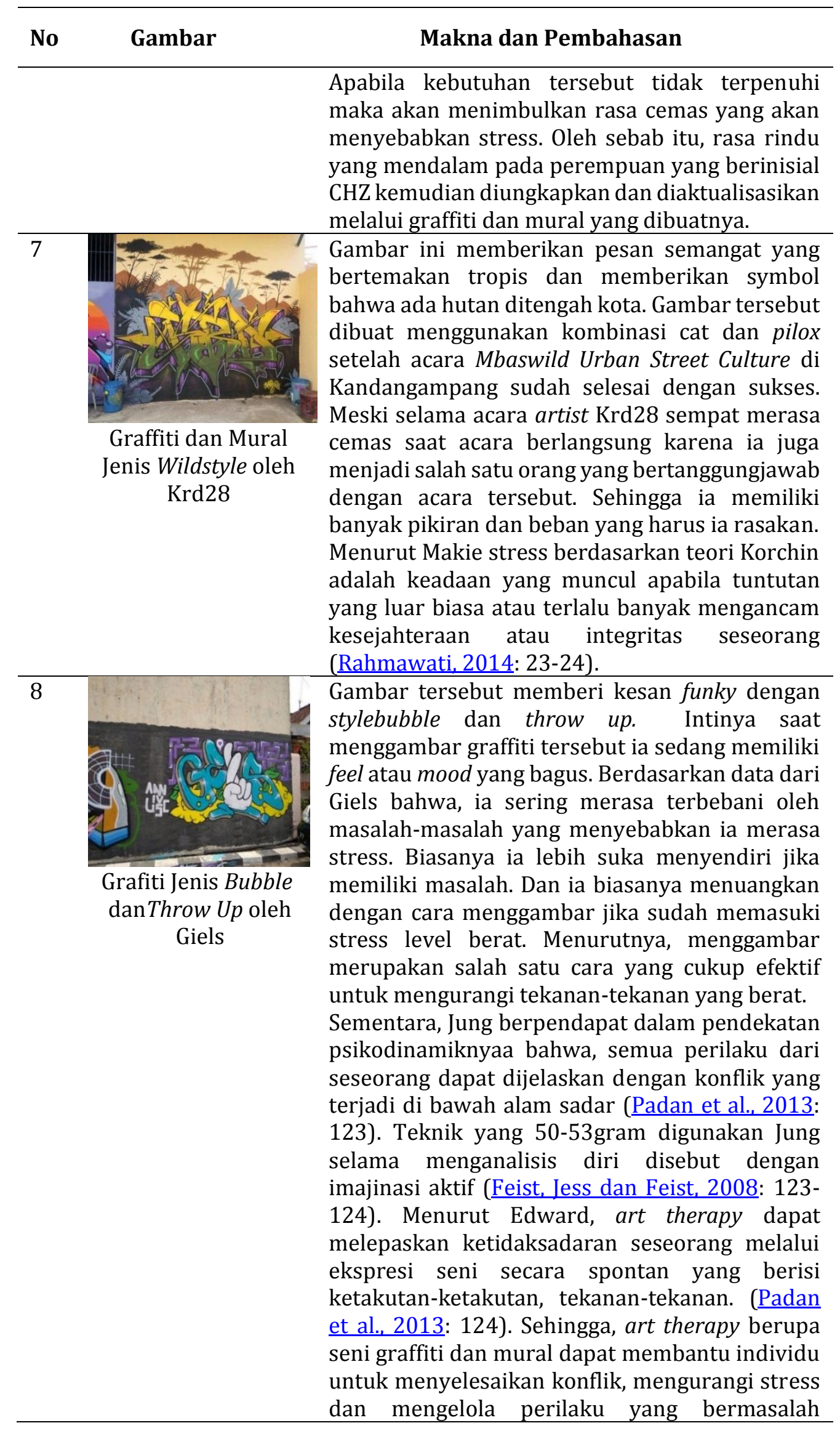




\begin{tabular}{lllll}
\hline No Gambar & \multicolumn{3}{c}{ Makna dan Pembahasan } \\
\hline & $\begin{array}{l}\text { sehingga bisa } \\
\text { diri/kepercayaan diri. }\end{array}$ & meningkatkan \\
\hline
\end{tabular}

\section{Kesimpulan dan Penutup}

Berdasarkan hasil skor pre-test dan post-test skala DASS dengan 42 butir pertanyaan terhadap komunitas Purbalingga Street Art (PUSAR) terdapat penurunan. Hasil uji statistik terdapat perbedaan atau penurunan tingkat stress yang signifikan pada subjek penelitian dengan hasil $\mathrm{p}$ value $=0,011$ ( $\mathrm{p}$ value $<0,05)$. Berdasarkan penghitungan ini, maka hipotesis diterima. Perbedaan kondisi stress sebelum dan sesudah pembuatan graffiti dan mural pada komunitas Purbalingga Street Art (PUSAR) terdapat pada masing-masing sampel yang dijadikan sebagai obyek penelitian. Dengan demikian, dapat disimpulkan bahwa graffiti dan mural dapat digunakan mampu mereduksi tingkat stress pada komunitas Purbalingga Street Art (PUSAR).

\section{Daftar Pustaka}

Jurnal

Abidin, M. Z. (2012). Model-Model Pengembangan Kajian Psikologi dalam Diskursus Pemikiran Muslim Kontemporer. Jurnal Religi, Vol 8 (1), Yogyakarta: UIN Sunan Kalijaga Press

Abidin, Z. (2009). Ketika Stress Beraksi Islam Punya Solusi. Jurnal Dakwah Dan Komunikasi, 3 (1), Purwokerto: Fakultas Dakwah

Anggraeni, Tania Puspa \& Miftakhul Jannah. (2014). Hubungan antara Psychological Well-Being dan Kepribadian Hardiness dengan Stres pada Petugas Port Securuty. Jurnal Character, 3(2) , Surabaya, UNESA

Asnita, Lina \& Arneliwati, J. (2015). Hubungan Tingkat Stress dengan Harga Diri Remaja di Lembaga Pemasyarakatan. JOM, 2 (2), Pekanbaru: Universitas Riau

Budyastomo, A. W. (2018). Bentuk Bahasa Komunikasi dalam Seni Grafiti Sebagai Media Peyampaian Pesan (Studi Kasus: Padepokan Grafiti Salatiga ). Jurnal Batoboh, 3(2), Padang: padangpanjang press

Fachmi Ramadani, Hairunnisa, S. (2018). Pesan Sosial dalam Seni Mural di Kota Samarinda. Jurnal Ilmu Komunikasi, Vol 6 (3), Samarinda

Feist, Jess dan Feist, G. J. (2008). Theories of Personality (Y. Santoso, Ed.). Yogyakarta: Pustaka Pelajar.

Badan Pengembangan Bahasa dan Perbukuan, Kamus Besar Bahasa Indonesia. (2018), Jakarta: Balai Pustaka

Khofifah, A. (2015). Gambaran Tingkat Stress pada Anak Usia Sekolah Menghadapi Menstruasi Pertama (Menarche) di SDN Gegerkalong Girang 2. Jurnal Pendidikan Keperawatan Indonesia, Vol I (2), Bandung: Universitas Pendidikan Indonesia

Masdar, H., Saputri, P. A., Rosdiana, D., \& Chandra, F. (2016). Depresi , ansietas , dan stres serta hubungannya dengan obesitas pada remaja. Jurnal Gizi Klinik Indonesia, 12(4), Yogyakarta: Universitas Gadjah Mada

Mukhlis, A. (2011). Pengaruh Terapi Membatik terhadap Depresi pada Narapidana. Jurnal Psikolslamika, Vol 8(1), Malang: UIN Malang

Padan, W. H., Roswita, M. Y., Hastuti, L. W., Therapy, A. R. T., Mengurangi, U., Pada, K., 
\& Yang, A. (2013). Art Therapy untuk Mengurangi Kecemasan pada Anak yang Baru Memasuki Panti Asuhan. Jurnal Prediksi, Kajian Ilmiah Psikologi, 2(1), Semarang: UNIKA Soegiyopranoto

Permatasari, A. E., Marat, S., \& Suparman, M. Y. (2017). Penerapan Art Therapy untuk Menurunkan Depresi pada Lansia di Panti Werdha X. Jurnal Muara Ilmu Sosial, Humaniora, dan Seni, 1(1), Jakarta: Universitas Tarumanegara

Rahmawati, M. (2014). Menulis Ekspresif sebagai Strategi Mereduksi Stres untuk Anak-anak Korban Kekerasan dalam Rumah Tangga (KDRT). Jurnal Ilmiah Psikologi Terapan, Malang: Universitas Negeri Malang

Rochman, K. L. (2010). Kesehatan Mental. Purwokerto: STAIN Press.

Sani, F. L. (2015). Fenomena Komunikasi Anggota Komunitas Graffiti di Kota Medan (Studi Fenomenologi pada Anggota Komunitas ME\&ART). Jurnal Ilmu Komunikasi, 2(1), Medan: Universitas Islam Sumatera Utara

Setiana, Dewa Gede Agung Agus \& Cristin Wiyani, R. E. (2017). Pengaruh Art Therapy (Terapi Menggambar) terhadap Stres pada Lansia. Jurnal Kebidanan Dan Keperawatan, 13 (2). Yogyakarta: Universitas Aisyiyah

Widagdo, M. B. (2016). Jurnal Ilmu Sosial Jurnal Ilmu Sosial. Jurnal Ilmu Sosial, Vol 15(1), Semarang: Universitas Diponegoro

Yuniar, R. (2017). Graffiti Sebagai Media Komunikasi Politik Kaum Urban. Naskah Publikasi. www. academi.edu

\section{Buku}

Asharhani, I. S. (2012). Mural dan Graffiti Sebagai Elemen Pembentuk Townscape. Skripsi. Purwokerto: Fakultas Dakwah

Priyono. (2008). Metode Penelitian Kuantitatif, Sidoarjo: Zifatama Publishing.

Purwandari, R. (2016). Hubungan Tingkat Kecemasan dengan Perilaku Ketergantungan Merokok pada Pengendara Becak Bermotor di Kelurahan Siringo-Ringo Rantauprapat. Skripsi, Medan: Universitas Labuan Batu

Sayekti, E. (2017). Stress Akademik pada Siswa Kelas XI MA Yarobi Kec. Grobogan, Kab. Grobogan. Skripsi, Semarang: Fakultas Dakwah dan Komunikasi UIN Walisongo

Sholihah, I. N. (2017). Kajian teoritis penggunaan art therapy dalam pelaksanaan layanan bimbingan dan konseling di SMK. PROCEEDINGS INTERNATIONAL CONFERENCE IAIN PURWOKERTO

Susanto, M. (2002). Diksi Rupa. Yogyakarta: Kanisius.

\section{Internet dan Wawancara}

Candra, C. O. (2013). Pesan Visual Mural Kota Karya Jogja Mural Forum - Yogyakarta. Skripsi, Yogyakarta: ISI

Clantwo. (2019). Wawancaran dalam Coolabs Talk 3, Street Art: Menantang Ruang untuk Berekspresi.

Diets. (2018). Wawancara dalam ulangtahun Urban Street Art (USC) ke-5.

Malchiodi, C. A. (2006). Expressive Therapies. Retrieved from https://www.psychologytoday.com/files/attachments/231/malchiodi3.pdf.

Milk. (2018). Wawancara dalam ulangtahun Urban Street Culture (USC) ke-5. 